Situs Jurnal : $\underline{\text { http://ejurnal.stiepancasetia.ac.id/index.php/jieb }}$

Jilid 4 Nomor 1 Maret 2018

Hal $029-035$

\title{
ANALISIS DAMPAK WISATA KAMPUNG PELANGI TERHADAP PENINGKATAN PENDAPATAN MASYARAKAT SEKITAR (PEDAGANG) DI KELURAHAN KEMUNING KECAMATAN BANJARBARU SELATAN
}

\section{Puji Hastuti* dan Diah Ismayanti}

Abstract : The purpose of this research is to see the impact of Kampung Pelangi tourist attraction to increase the income of the surrounding community, especially traders in Kemuning Village, South Banjarbaru. Research data using primary and secondary data. Data analysis techniques used using multiplier effect (cash flow) that occurred. The result of the research is generally the activity of tourists able to give impact $30.57 \%$, the value is able to give improvement of income economy for society specially merchant that exist around the tourism object. And the direct impact Ratio felt by the local community from the expenditure of visitors or tourists is $3.22 \%$. Thus the more tourists who come to visit it will be greater give direct impact on the economy of the surrounding community.

\section{Keywords: Tour Impact, Increasing Community Income, Kampung Pelangi}

Abstrak: Tujuan dari penelitian ini adalah untuk melihat dampak objek wisata Kampung Pelangi terhadap peningkatan pendapatan masyarakat sekitar terutama pedagang di Kelurahan Kemuning Banjarbaru Selatan. Data penelitian menggunakan data primer dan sekunder. Teknik analisa data yang digunakan menggunakan efek pengganda (Multiplier) arus uang yang terjadi. Hasil dari penelitian adalah secara umum kegiatan wisatawan mampu memberikan dampak sebesar $30.57 \%$, nilai tersebut mampu memberikan peningkatan ekonomi pendapatan bagi masyarakat khususnya pedagang yang ada di sekitar objek wisata tersebut. Dan secara Rasio dampak langsung yang dirasakan oleh masyarakat lokal dari pengeluaran pengunjung atau wisatawan adalah sebesar 3,22\%. Dengan demikian semakin banyak wisatawan yang datang berkunjung maka akan lebih besar memberikan dampak secara langsung terhadap ekonomi masyarakat sekitarnya.

Kata kunci : Dampak Wisata, Peningkatan Pendapatan Masyarakat, Kampung Pelangi.

\section{Latar Belakang}

Bertambahnya jumlah penduduk di suatu daerah menuntut Pemerintah untuk menyediakan berbagai fasilitas yang biasa untuk digunakan masyarakat secara umum, baik prasarana maupun sarana. Prasarana dan sarana berperan sebagai fasilitas yang dibutuhkan masyarakat luas yang penyediaannya dilakukan secara serentak atau massal.

Tingkat pemenuhan kebutuhan fasilitas tersebut menjadi ukuran tingkat kesejahteraan masyarakat. Penyediaan prasarana dan sarana umum merupakan tanggung jawab pemerintah karena menyangkut hajat hidup orang banyak, baik untuk memenuhi kebutuhan pokok seharihari maupun kebutuhan sekunder. Penyediaan prasarana dan sarana umum tersebut antara lain mencakup jaringan jalan, listrik, air minum, gas, saluran pembuangan limbah cair, sampah dan jaringan telepon. Selain itu tidak kalah pentingnya adalah penyediaan tempat-tempat objek wisata untuk di nikmati oleh masyarakat sekitarnya. 
Sebagai makhluk sosial, manusia mempunyai kebutuhan yang beraneka ragam, dari kebutuhan primer, yaitu (pangan), kebutuhan sekunder yaitu pakaian (sandang), hingga kebutuhan tersier, yaitu kebutuhan akan tempat tinggal (papan). Berkembangnya peradaban tidak hanya membuat seseorang memerlukan kebutuhan primer dan sekunder, tetapi juga memerlukan kebutuhan untuk bersantai atau berlibur menjadi kebutuhan yang tidak dapat dipisahkan dalam kehidupan manusia modern.

Menurut Undang-undang Kepariwisataan No. 10 tahun 2009, yang dimaksud dengan pariwisata adalah berbagai macam kegiatan wisata yang didukung oleh berbagai fasilitas serta pelayanan yang disediakan oleh masyarakat, pengusaha, pemerintah dan pemerintah daerah. (Prasiasa, 2013:7).

Industri pariwisata mampu memberikan sumbangan terhadap penerimaan devisa yang sangat diperlukan untuk membiayai pembangunan nasional ataupun daerah tertentu. Selain dapat memberikan pendapatan devisa bagi negara, sektor pariwisata juga memberikan kontribusi terhadap pendapatan yang diterima oleh pemerintah pusat maupun daerah, yaitu yang bersumber dari pajak dan retribusi.

Adanya pengeluaran yang dilakukan oleh wisatawan, diharapkan dapat meningkatkan pendapatan yang diterima oleh masyarakat setempat. Manfaat lain yang diperoleh dari pengembangan pariwisata adalah terciptanya lapangan kerja. Lapangan kerja yang tercipta dari industri pariwisata dapat digolongkan ke dalam tiga kelompok, yaitu lapangan kerja langsung, lapangan kerja tidak langsung dan lapangan kerja ikutan. Lapangan kerja langsung adalah pekerjaan-pekerjaan yang tersedia pada jajaran dan industri pariwisata, misalnya akomodasi, transportasi, restoran, biro perjalanan, daya tarik wisata, dan fasilitas bisnis pariwisata. Lapangan kerja tidak langsung adalah pekerjaan-pekerjaan yang tersedia pada pabrik, toko, dan usaha-usaha lain yang diperlukan oleh pengusaha di luar pariwisata untuk melayani wisatawan secara tidak langsung, misalnya sektor pertanian, perkebunan, peternakan, perikanan, industri manufaktur dan industri jasa. Lapangan kerja ikutan adalah lapangan kerja yang tercipta akibat dari pengeluaran orang-orang yang bekerja secara langsung maupun tidak langsung pada industri pariwisata. (Prasiasa, 2013 : 11)

Wisata Kampung Pelangi yang terletak di Kelurahan Kemuning, Kecamatan Banjarbaru Selatan, dahulunya adalah sebuah kampung yang kumuh dan sungai-sungai yang di sekitar kampung tersebut sangat kotor, karena banyaknya sampah yang terlihat di sungai tersebut. Sekitar dua bulan terakhir Kawasan Sungai Kemuning di Kelurahan Kemuning Desa Guntung Paikat, Banjarbaru Selatan tampilannya berubah drastis. Daerah yang padat permukiman ini sebelumnya terlihat kumuh dengan jajaran rumah menjorok ke sungai, namun sekarang mulai ditata rapi.

Berdasarkan hasil wawancara dari perwakilan RT setempat diperoleh informasi bahwa ada 5 RT yang rumahnya mendapat bantuan dari Pemerintah berupa Cat untuk mempercantik bangunan milik warga. Awalnya warga yang mengusulkan ke Pemerintah dan ternyata direspon baik, akhirnya kampung yang dulu kumuh sekarang menjadi kampung yang indah dan rapi, tidak terlihat lagi adanya bangunan yang semraut, melainkan berubah menjadi pedestrian cantik yang dilengkapi dengan sarana tempat duduk untuk bersantai, sejuk karena banyak pepohonan dan bila malam tiba banyak lampu kelap kelip serta warna-warni yang menghiasi tempat tersebut. Tak hanya dicat warna-warni, setiap bangunan warga diberi gambar bermacam-macam seperti hewan, aktifitas manusia yang berkaitan dengan unsur kedaerahan.

Pemerintah Kota Banjarbaru sangat berperan aktif dalam pengembangan Kampung Pelangi, hal ini terlihat dari keseriusan pemerintah untuk menjadikan Kampung Pelangi sebagai Destinasi Wisata yaitu dengan mendatangkan 10 orang pelukis yang termuat dalam komunitas senirupa Banjarbaru untuk menggambar di tempat-tempat tersebut. 
Seperti hasil wawancara dari sebagian warga, bahwa bila momen akhir pekan datang banyak warga dari luar kampong yang datang, baik dari dalam maupun dari luar Banjarbaru. Diharapkan kampung pelangi menjadi destinasi wisata baru untuk wilayah Banjarbaru dan sekitarnya. Situasi ini dimanfaatkan oleh warga setempat dengan membuka warung sekedar berjualan makanan dan minuman ringan bagi pengunjung. Bahkan sebagian warga ada yang berinisiatif menyediakan lahan tempat parkir kendaraan, ada juga yang menyediakan jasa pemancingan dan tempat-tempat untuk berolah raga. Dengan adanya objek Wisata Kampoeng Pelangi ini diharapkan mampu meningkatkan pendapatan masyarakat sekitar khususnya bagi para pedagang yang ada di sekitar tempat wisata tersebut.

Berdasarkan latar belakang tersebut diatas, maka penulis tertarik untuk menganalisis "Dampak Pariwisata Kampung Pelangi Terhadap Peningkatan Pendapatan Masyarakat Sekitar (Pedagang) Di Kelurahan Kemuning Banjarbaru Selatan"

Penelitian ini merupakan penelitian yang bersifat deskriptiff kuantitatif yang bertujuan untuk melihat dampak objek wisata Kampung Pelangi terhadap peningkatan pendapatan masyarakat sekitar terutama pedagang di Kelurahan Kemuning Banjarbaru Selatan.

\section{Kajian Literatur}

Pariwisata berasal dari bahasa Sansekerta yang terdiri dari dua kata, yaitu kata "pari" berarti penuh, seluruh atau semua, dan kata "wisata: yang bermakna perjalanan. Menurut Wahab dalam Bagus (2016;02) pariwisata mengandung tiga unsur antara lain; manusia, yaitu unsur insani sebagai pelaku kegiatan pariwisata; tempat, yaitu unsur fisik yang sebenarnya tercakup oleh kegiatan itu sendiri; dan waktu, yaitu tempo yang dihabiskan dalam perjalanan tersebut dan selama berdiam di tempat tujuan.

Jadi, definisi pariwisata adalah salah satu dari industri baru yang mampu meningkatkan pertumbuhan ekonomi dengan cepat dalam hal kesempatan kerja, pendapatan, taraf hidup dan dalam hal mengaktifkan sektor produksi lain di dalam negara penerima wisatawan. Sedangkan menurut UU No. 09 Tahun 1990, tentang kepariwisataan pariwisata adalah kegiatan yang bertujuan menyelenggarakan jasa pariwisata, menyediakan atau mengusahakan objek dan daya tarik wisata, usaha sarana pariwisata dan usaha lain yang terkait di bidang tersebut. Usaha pariwisata berdasarkan UU tersebut digolongkan menjadi:

1. Usaha Jasa Pariwisata

Dikelompokkan menjadi; Jasa biro perjalanan wisata, Jasa agen perjalanan, usaha jasa pramuwisata, usaha jasa konvensi, jasa impresariat, jasa konsultasi pariwisata dan jasa informasi pariwisata.

2. Pengusahaan objek dan daya tarik wisata

Dikelompokan menjadi; pengusahaan objek dan daya tarik wisata alam; pengusahaan objek dan daya tarik wisata budaya; dan pengusahaan objek dan daya tarik wisata minat khusus.

3. Usaha sarana pariwisata.

Dikelompokan menjadi; penyediaan akomodasi; penyediaan makanan dan minuman; penyediaan angkutan wisata; penyediaan sarana wisata tirta; dan penyediaan kawasan pariwisata.

Pariwisata adalah salah satu mesin penggerak perekonomian dunia yang terbukti mampu memberikan kontribusi terhadap kemakmuran sebuah negara. Pembangunan pariwisata mampu menggairahkan aktivitas bisnis untuk menghasilkan manfaat sosial, budaya, dan ekonomi yang signifikan bagi suatu negara. 
Menurut Bagus (2016;7) berdasarkan perspektif ekonomi, pariwisata mempunyai dampak positif, yaitu : 1) mendatangkan devisa; 2) pasar potensial bagi produk barang dan jasa masyarakat setempat; 3) meningkatkan pendapatan masyarakat yang kegiatannya terkait langsung atau tidak langsung dengan jasa pariwisata; 4) memperluas penciptaan kesempatan kerja, baik pada sektor-sektor yang terkait langsung seperti perhotelan, restoran, agen perjalanan, maupun pada sektor-sektor yang tidak terkait langsung seperti industri kerajinan, penyediaan produk-produk pertanian, atraksi budaya, bisnis eceran, jasa-jasa dll; 5) sumber pendapatan asli daerah (PAD); dan 6) merangsang kreativitas seniman, baik seniman pengrajin industri kecil maupun seniman 'tabuh' dan tayang diperuntukkan konsumsi wisatawan.

Berdasarkan penjelasan tersebut diatas, maka dapat disimpulkan bahwa pariwisata dapat menimbulkan dampak positif (Positive impact) bagi perekonomian regional dan nasional, namun disamping dampak yang positif pariwisata dapat juga menimbulkan dampak yang negative (negative impact) antara lain; menyusutnya lahan pertanian untuk pembangunan pendukung infrastruktur pariwisata, meningkatnya kriminalitas, kepadatan lalu lintas, urbanisasi dan emigrasi, bermunculan ruko-ruko. Shopping center yang melanggar tata ruang wilayah, degredasi lingkungan dan polusi.

Sedangkan menurut Pitana \& Diarta $(2009 ; 1840)$ mengemukakan dampak pariwisata terhadap kondisi sosial ekonomi masyarakat lokal dapat dikategorikan menjadi delapan kelompok, yaitu:

1. Dampak terhadap penerimaan devisa

2. Dampak terhadap pendapatan masyarakat

3. Dampak terhadap kesempatan kerja

4. Dampak terhadap harga-harga

5. Dampak terhadap distribusi manfaat/keuntungan

6. Dampak terhadap kepemilikan dan control

7. Dampak terhadap pembangunan pada umumnya, dan

8. Dampak terhadap pendapatan pemerintah.

Sebagaimana yang telah dijelaskan diatas bahwa pariwisata tidak hanya menimbulkan dampak positif saja tetapi dapat juga menimbulkan dampak yang negatif. Menurut Pitana \& Diarta $(2009 ; 185)$ menyebutkan bahwa dampak positif pariwisata bagi ekonomi yaitu, 1). Pendapatan dari penukaran valuta asing; 2). Menyehatkan neraca perdagangan luar negeri; 3). Pendapatan dari usaha atau bisnis pariwisata; 4). Pendapatan Pemerintah; 5). Penyerapan Tenaga Kerja; 6). Multiplier Effects; dan 7). Pemanfaatan fasilitas Pariwisata oleh Masyarakat Lokal. Disamping memberikan dampak yang positif keberadaan pariwisata juga menimbulkan dampak yang negatif, yaitu: 1). Ketergantungan terlalu besar pada pariwisata; 2). Meningkatkan angka inflasi dan meroketnya harga tanah; 3). Meningkatnya kecenderungan untuk mengimpor bahan-bahan yang diperlukan dalam pariwisata; 4). Sifat pariwisata yang musiman, tidak dapat diprediksi dengan tepat, menyebabkan pengembalian modal investasi juga tidak pasti waktunya; dan 5). Timbulnya biaya-biaya tambahan lain bagi perekonomian setempat.

Penelitian yang telah dilakukan oleh Irianto, agus, dkk (2010) menyatakan bahwa ratarata masyarakat sekitar obyek wisata di Sumatera Utara telah mampu memenuhi penghidupannya dengan berusaha disekitar obyek wisata dan obyek wisata telah mapu berperan serta dalam meningkatkan pendapatan masyarakat sekitar. Penelitian sejenis yang juga telah dilakukan oleh Dritasto, Achadiat dan Annisa Ayu (2013) memberikan hasil bahwa keberadaan wisata di Pulau Tidung telah memberikan dampak ekonomi terhadap perekonomian masyarakat lokal. Eduart Wotok (2016) juga melakukan penelitian yang menghasilkan bahwa wisata bahari memberikan dampak ekonomi terhadap pendapatan masyarakat didesa Batu barani, walaupun berada dalam kategori rendah dan belum dirasakan secara merata oleh masyarakat. 
Begitu juga dengan hasil penelitian yang dibuat oleh Aryunda (2011) menyatakan bahwa kegiatan ekowisata memberikan peningkatan pendapatan dikepulauan seribu, menyediakan lapangan pekerjaan dan terjadinya peningkatan penerimaan daerah.

\section{Metode Penelitian}

Penelitian ini dilaksanakan di Keluruahan Kemuning Banjarbaru Selatan. Data penelitian menggunakan data primer dan sekunder, sedangkan teknik pengumpulan data menggunakan wawancara, observasi dan angket. Sampel yang di ambil adalah masyarakat pedagang di sekitar wilayah objek wisata sebayak 25 orang pedagang yang ada di bantaran sungai Kemuning Banjarbaru, dan juga pengunjung (wisatawan) yang diambil sampelnya sebanyak 25 orang yang berkunjung ke objek wisata Kampung Pelangi di Kelurahan Kemuning Banjarbaru.

Metode yang digunakan dalam penelitian ini adalah deskriptif yaitu suatu metode dalam meneliti status manusia, suatu objek, suatu kondisi, suatu pemikiran ataupun suatu kelas peristiwa pada masa yang akan datang (Sugiono, 2015; 118). Selain itu metode Deskriptif ini mempunyai tujuan membuat deskripsi, gambaran atau lukisan secara matematis, faktual dan akurat mengenai fakta-fakta, sifat-sifat serta hubungan antar fenomena yang diselidiki

Teknik analisa data yang digunakan menggunakan efek pengganda (Multiplier) arus uang yang terjadi. Untuk mengukur dampak ekonomi suatu kegiatan wisata terhadap perekonomian masyarakat lokal menggunakan dua tipe pengganda, yaitu (Vanhove, 2005) :

1. Keynesian Local Income Multiplier, yaitu nilai yang menunjukkan berapa besar pengeluaran pengunjung berdampak pada peningkatan pendapatan masyarakat lokal.

2. Ratio Income Multiplier, yaitu nilai yang menunjukkan seberapa besar dampak langsung yang dirasakan dari pengeluaran pengunjung berdampak terhadap perekonomian lokal.

Secara matematis dapat dirumuskan sebagai berikut:

Keynesian Income Multiplier $=\frac{\mathrm{D}+\mathrm{N}+\mathrm{U}}{\mathrm{E}}$

Ratio Income Multiplier, Tipe $\mathrm{I}=\frac{\mathrm{D}+\mathrm{U}}{\mathrm{D}}$

Ratio Income Multiplier, Tipe $\mathrm{II}=\frac{\mathrm{D}+\mathrm{N}+\mathrm{U}}{\mathrm{D}}$

Dimana:

$\mathrm{E}=$ Tambahan pengeluaran pengunjung (rupiah)

$\mathrm{D}=$ Pendapatan local yang diperoleh secara langsung dari E (rupiah)

$\mathrm{N}=$ Pendapatan local yang diperoleh secara tidak langsung dari E (rupiah)

$\mathrm{U}=$ Pendapatn local yang diperoleh secara Induced dari E (rupiah)

Nilai Keynesian Lokal Income Multiplier, Ratio Income Multiplier Tipe I, dan Ratio Income Multiplier Tipe II memiliki kriteria-kriteria sebagai berikut:

1. Apabila nilai-nilai tersebut kurang dari atau sama dengan nol $(\leq 0)$, maka lokasi wisata tersebut belum mampu memberikan dampak ekonomi terhadap kegiatan wisatanya,

2. Apabila nilai-nilai tersebut diantara nol dan satu $(0<\mathrm{x}<1)$, maka lokasi wisata tersebut masih memiliki nilai dampak ekonomi yang rendah dan,

3. Apabila nilai-nilai tersebut lebih besar atau sama dengan satu $(\geq 1)$, maka lokasi wisata tersebut telah mampu memberikan dampak ekonomi terhadap kegiatan wisatanya. 


\section{Hasil Penelitian Dan Pembahasan}

Keberadaan Wisata Kampung Pelangi memberikan dampak bagi masyarakat sekitar, khususnya masyarakat pedagang yang ada di sekitar Wisata Kampung Pelangi. Dampak yang timbul akibat adanya perubahan kegiatan Wisata Kampung Pelangi tersebut adalah adanya perubahan ekonomi masyarakat khususnya bagi pedagang-pedagang yang ada di sekitar objek wisata Kampung Pelangi. Dampak yang timbul dari adanya kegiatan wisata Kampung Pelangi tersebut dapat bersifat langsung maupun tidak langsung.

Berdasarkan hasil data angket responden dengan perhitungan Keynesian Multiplier Efek di dapat hasil bahwa:

1. Kegiatan Wisata Kampung Pelangi memberikan dampak secara ekonomi bagi masyarakat lokal, khususnya pedagang yaitu sebesar 30,57\%, hal ini menunjukan bahwa nilai tersebut lebih besar dari satu yang artinya objek wisata tersebut mampu memberikan dampak secara ekonomi terhadap peningkatan pendapatan masyarakat lokal khususnya pendapatan masyarakat pedagang yang ada di sekitar lokasi wisata Kampung Pelangi.

2. Besarnya Rasio dampak langsung yang dirasakan oleh masyarakat lokal khususnya masyarakat pedagang yang ada di sekitar lokasi wisata terhadap peningkatan ekonomi masyarakat adalah sebesar 3,22 \%, hal ini menunjukan bahwa keberadaan wisata Kampung Pelangi memberikan dampak secara langsung yang dapat di rasakan oleh masyarakat khususnya masyarakat pedagang yang ada di daerah bantaran sungai kemuning.

\section{Kesimpulan}

Wisata Kampung Pelangi yang terletak di Kelurahan Kemuning Kecamatan Banjarbaru Selatan yang dalam perkembangannya di kelola langsung oleh masyarakat setempat. Dengan keterkaitan masyarakat dalam kegiatan tersebut dapat memberikan dampak terhadap ekonomi pendapatan masyarakat khususnya bagi pedagang-pedagang yang ada di sekitar lokasi wisata tersebut.

Secara umum kegiatan wisatawan mampu memberikan dampak sebesar $30.57 \%$, nilai tersebut mampu memberikan peningkatan ekonomi pendapatan bagi masyarakat khususnya pedagang yang ada di sekitar objek wisata tersebut. Dan secara Rasio dampak langsung yang dirasakan oleh masyarakat lokal dari pengeluaran pengunjung atau wisatawan adalah sebesar $3,22 \%$. Dengan demikian semakin banyak wisatawan yang datang berkunjung maka akan lebih besar memberikan dampak secara langsung terhadap ekonomi masyarakat sekitarnya.

\section{DAFTAR PUSTAKA}

Andi Mappi, 2001, Cakrawala Pariwisata. Balai Pustaka, Jakarta

Aryunda, Hanny, 2011. Dampak Ekonomi Pengembangan Kawasan Ekowisata Kepulauan Seribu. Jurnal Perencanaan Wilayah dan kota. Vol.22 No.1 April

Dewa Putu Oka. P, 2013. Destinasi Pariwisata Berbasis Masyarakat. Salemba Humanika, Jakarta

Dritasto, Achadiat dan Annisa Ayu, 2013. Analisa Dampak Ekonomi Wisata Bahari Terhadap

Pendapatan Masyarakat di Pulau Tidung. Jurnal Institusi Teknologi Nasional.

I Gede Pitana, 2009, Pengantar Ilmu Pariwisata, Andi Yogyakarta, Yogyakarta

I Gede Bagus Rai Utama, 2016, Pemasaran Pariwisata, Andi Offset. Yogyakarta

Irianto, agus, dkk, 2010. Dampak Pariwisata Terhadap Peningkatan Pendapatan Masyarakat Sumatera Utara.

Rio Budi Prasadja, 2013, Kunci Sukses Memasarkan Jasa Pariwisata. Jakarata

Prasetyo, Bambang dan Lina M.Jannah. 2005. Metode Penelitian Kualitatif. Jakarta. PT Raja Grafindo Persada 
Vanhove, N. 2005. The Economics of Tourism Destinations. Elsevier Butterworth-Helnemann, Oxford University. United Kingdom.

Wolok, Eduart. 2016. Analisis Dampak Ekonomi Wisata Hiu Paus Terhadap Pendapatan Masyarakat Batubarani Gorontalo. Jurnal Ekonomi Bisnis dan Kewirausahaan, Vol.5 No.2 Agustus. 